\title{
Accounting for Men's Work: Multiple Employments and Occupational Identities in Early Modern England
}

\author{
by K. Tawny Paul
}

University of Exeter

T.Paul@exeter.ac.uk

Like most people in the eighteenth century, Edmund Harrold made his living by working multiple jobs. A barber by training and title, he rented a small shop in Manchester where he shaved customers' heads, bought and sold hair, and crafted wigs. In the hours unfilled by shaving, cutting and weaving, he also performed 'cupping', a medical service offered to lactating women. In addition to these principal employments, Harrold undertook other temporary income-generating activities or by-employments. He worked as a book dealer, and eventually as an auctioneer, selling various items in alehouses within Manchester and in outlying towns. In 1713, when times got hard, Harrold took on paid employment offered by civic authorities and worked as a dog muzzler. He lent out money, when he had it, earning ten percent interest on his holdings. Harrold's household also depended upon the productive activities undertaken by his wife and dependents. His wife Sarah managed the rental of a room in their house to lodgers, retailed second-hand clothing, and operated a business washing clothes. In addition to these income-generating activities, Sarah contributed to the household's maintenance by producing foodstuffs including bread. ${ }^{1}$

Edmund Harrold's experience of multiple employments, described in a diary that he kept between 1712 and 1715, was typical of the occupational fluidity that characterized eighteenth-century working lives. Whether measured by the tools and goods in probate inventories, the work or maintenance activities described by the litigants and witnesses in court records, or the debts that individuals contracted, we know that occupational titles did not fully describe men's productive activities and that occupational plurality was the norm. Individuals tended to combine different forms of work, and to move during their lives from one form of employment to another. ${ }^{2}$ For Harrold and others, this occupational plurality was a feature of maintaining what he described as a 'computency of living' in a precarious economic environment. ${ }^{3}$ 
Studies of by-employment tend to focus on the prevalence of supplementary work in financial terms. The frequency with which individuals took on subsidiary work, the methodologies that we use to measure by-employment, and the amount of income generated by a person's different productive activities are all contested issues. ${ }^{4}$ Yet when considering men's work, we have largely failed to account for by-employment in terms of identity. This is a significant oversight, because work was about much more than getting by. As Jonas Lindström, Rosemarie Fiebranz and Göran Rydén recently commented, lists of what people did do not tell us what work meant to them. ${ }^{5}$ Among other things, work provided a central component of masculine selfhood. According to Keith Thomas, for those who laboured to get their living, work was 'not a means to an end, but an end in itself; not a job, but a vocation'. ${ }^{6}$ Clearly, Harrold's sense of self and his feeling of being satisfied with his work was about more than being supported by his earnings or as he put it, his 'bargains'.

The precarious world of early modern labour contributed to the struggle for a secure work-based identity. Sociologists have found that those engaged in gig economies today may piece together a decent living, but they experience 'failed occupationality'. In other words, they are unable to assume stable occupational identities. This can have consequences for an individual's sense of fulfilment and selfhood. ${ }^{7}$ As Harrold reflected in his diary, 'I think well of my bargain in general, but for the wanderings and settledness of human nature that's never satisfied, I find it hardest to please self' ${ }^{8}$ Though the concept of 'failed occupationality' might seem an anachronism in a period when few people could expect stable occupational identities, we continue problematically to associate men with single occupations. In the literature of the time, character attributes, bodily characteristics and physical deformities were linked with particular trades, suggesting that occupational identity was a permanent condition. Men identified their worth or status by single occupations in legal and administrative records. In these settings, claiming an occupation was an important feature of solidarity and social distinction, used by middling people to distinguish themselves from those who lived by merely their labour. ${ }^{9}$ What happened to this sense of occupational identity, however, when men did multiple jobs - when, as in Harrold's case, a wigmaker was in practice not a wigmaker, but a wigmaker, bookseller, medical practitioner and landlord? 
Much of the research on the nuances of work and working identities has focused on female labour. Accounting for women's productive activities, which often sat outside of the formal occupational record, has required the development of new methodologies demanding that the historian look beyond the world of occupational titles. Yet while we have been attentive to the specificities and nuances of women's work, we make assumptions about the nature of men's work. In 1984, perhaps reading an insight of the women's movement back onto the historical past, Mary Prior wrote that 'What men did was definite, well defined, limited... What the women did was everything else'. ${ }^{10}$ Occupational titles, Prior believed, clearly delineated men's productive activities. Over thirty years later, we are little closer to understanding the forms and meanings of male labour. As the pioneering 'Gender and Work' project in Sweden has made clear, we know remarkably little about both male and female work. ${ }^{11}$ Even if single occupations were understood at the time to be fictions, or at least transitory or temporary, these remnants of the archive continue to influence how historians think about men's work.

An investigation of what different working activities meant to men offers an opportunity to apply some of the insights developed around women's work to the male experience, and to challenge our conceptualization of men's working identities in two key ways. First, we need to reconsider the relationship between different kinds of productive activities. Though by-employments are normally considered to provide supplementary income while a person's primary occupation provided their principal means of maintenance, we might position the status of different working activities differently if we consider them in terms of worth, skill, and reputation rather than just income. What kinds of benefits did different working activities confer? When men did multiple jobs, which occupation did they choose as their source of public identity, and why? This will allow us to account for male productive activity that was not paid. Second, we need to think about the meanings and identity implications of different forms of multiple-employment. By-employment can include forms of work undertaken by men at one point in time, the multiple and changing activities that individuals undertook across their lives, and the multiple productive activities undertaken by dependents within a household. ${ }^{12}$ Recognizing different forms of occupational plurality is useful to reconstructing male occupational identities because it allows us to consider work as a collective endeavour performed in relation to other people, and because it 
encourages us to attend to issues of life-cycle. An understanding of working identities that takes occupational plurality into account seems especially important in the eighteenth century, a period when, as Alex Shepard argues, people came to account for their worth more in terms of what they did than in terms of the material wealth that they had, and when, as John Rule suggests, skill and knowledge came to be considered forms of property. ${ }^{13}$

To consider the relationship between identity, masculinity and occupational plurality, it is necessary to look beyond formal administrative and legal records, where men were identified by either their occupational title, or their lack of one. In this article, I draw upon the diaries of three lower middling tradesmen: Thomas Parsons (17441813; diary 1769), a stone carver working in Bath, who was also an amateur scientist; John Cannon (1684-approx. 1743; diary 1735-43), agricultural labourer, exciseman, failed maltster, and teacher in the West Country, and the Manchester barber and wigmaker Edmund Harrold (1678-1721; diary 1712-15). ${ }^{14}$ The diaries provide glimpses of men at different points in the life-cycle, and with different experiences of occupational fluidity. Parsons was twenty-five years old when he penned the diary. Cannon's memoir reflected over several decades of working life, while Harrold was in mid-life, married with children, and the head of his household. All three men experienced financial precariousness. Cannon described himself as the "tennis-ball of fortune', and Parsons and Harrold struggled constantly with debt. Though the three diarists were clustered in the middle ranks of society, their experiences of occupational plurality, working identities, and the gendering of work within the household have implications for how we understand the working lives of a broader group of men. Most men in eighteenth-century Britain, except the very elite, worked for a living. Most held multiple employments, even if these contributed to different ends. For the better-off, byemployment was about maintaining competency and independence, while for the poor this was conceptualized as 'making shift' (avoiding poverty). Most men depended upon the contributions of their wives. The ideal of domesticity and a non-working wife did not emerge until the very end of the century. ${ }^{15}$

The three tradesmen did not pen their diaries with the explicit intention of keeping account of their work. However, in these texts, all three wrote extensively about their working lives, positioning labour within social, economic and religious practices. 
Parsons, a devout Baptist, and Harrold, a devout Anglican, both wrote with a religious impetus. By contrast, Cannon's writing practices were more secular. He wrote as a form of participation in the eighteenth-century world of letters. However, though written with different motivations, the diaries intersect within the project of self-fashioning, which brought together religious and secular interests. ${ }^{16}$ When confronted with the uncertainties associated with working life, diaries provided all three men with spaces to 'account' for themselves within their communities. ${ }^{17}$ Writing was a form of selfexamination that involved recounting one's actions as a means of securing creditworthiness with the community. In the pre-modern economy, credit was crucial to getting by. It had a dual meaning both as a financial instrument and as a form of reputation and trustworthiness. Securing the credit of one's household and one's self was a task important enough that we might even consider diary-keeping a form of work itself. $^{18}$

In their diaries, all three men reflected upon their employment in complex and multi-faceted ways: in terms of the income and the competency of living which their work afforded, in terms of the sense of self and status that they derived from these activities, and in terms of the spiritual concerns that shaped their management of wealth. Diaries combined narrative entries and social accounts with descriptions of items purchased and sold, goods lent and borrowed, work and services contracted and performed, and sermons heard and read. They accounted for their work, not just in terms of the pounds, shillings and pence that they earned, but in terms of the status, knowledge and relationships with others that work afforded.

\section{DEFINING WORK}

Evidence drawn from diaries contributes to the project of defining work, an issue of much recent historiographical interest. The simple definition of work as 'incomegenerating activity' is now largely considered inadequate because it is limited to monetized labour, and excludes both the numerous forms of unpaid work that took place within early-modern households, as well as non-monetized forms of trade. Alternatively, broader verb-oriented and time-use approaches have defined work as the 'use of time with the goal of making a living'. ${ }^{19}$ This methodology emphasizes what people did rather than what they were, and it has the capacity to include both monetized 
and non-monetized labour. The 'third party criterion', related to the verb-orientated approach, posits that anything that could be replaced with paid services or purchased should be considered work. ${ }^{20}$ However, these expansive definitions of work, which provide more inclusive understandings of production, have been more readily applied to women than to men in the early modern context.

The diaries of the three tradesmen enhance historical definitions of work by providing insights into how individuals classified their own activities. These contemporary categorizations suggest that, in accounting for men's labour, like women's, we must move beyond definitions of work that emphasize only monetary remuneration. Just as definitions of capital distinguish between economic, social and cultural forms, so work had economic, social and cultural benefits. ${ }^{21}$ While historians normally use 'work' as a label for the variety of things that individuals did to make a living, contemporaries had a diverse lexicon that sorted work into different categories according to function and fulfilment, and in which different tasks were afforded different forms of status.

The three diarists described their work using primarily three different words: 'business', 'work' and 'living'. Thomas Parsons used the word 'business' when describing the management of his stone-cutting work. He described his daily activities as 'Business which comprehends writing drawing, giving directions to others - working myself - and a great variety of articles that must constantly be remember' $d$ to prevent confusion'. ${ }^{22}$ Similarly, Edmund Harrold used the word 'business' when referring to his capacity to earn an income and to remain solvent. He frequently thanked God for 'good business'. In 1713, he recounted purchasing hair on credit 'upon necessity to put on business if I can'. 23 'Business', therefore, was the process by which individuals converted their labour and their credit into a living.

For both Parsons and Harrold, business had strong connotations of management. Their uses of the word reflected contemporary definitions of business as a pursuit demanding time and attention, distinctive from a pastime. 'Business' bore a strong relationship with the notion of oeconomy. Broadly understood to mean the management of resources according to an ordered system, oeconomy, as Karen Harvey suggests, came to define male governance over the household, where it constituted one of the important routes to patriarchal status and honour. ${ }^{24}$ While oeconomy anchored men to 
the home, it was also a crucial feature of work. Successful business was therefore not just about deriving an income, but about the appropriate management of resources, people, relationships, credits and debts. Harrold, for example, described the business of managing a bargain, recounting 'I swapt Spark for 19 pampheletts and books with John Brook. And so Im for turning about the business if I can'. ${ }^{25}$ The management activity associated with business was often a source of anxiety. Parsons noted at one point that 'Business increases my perplexity and confusion' ${ }^{26}$

The undertaking of 'business' was at least partly conceptualized in religious terms, which may temper Margaret Hunt's assertions that middling business people understood their wealth and their work in increasingly secular terms rather than in terms of divine providence. ${ }^{27}$ For the diarists, appropriate management was not signalled by maximizing profits, but rather by arranging resources according to a code of Christian ethics. Harrold and Parsons considered the possession of resources and the availability of work to be a feature of divine providence, and management of those resources a matter of religious duty. Harrold frequently thanked god for the provision of work. In 1712 he wrote 'I had a good business to day, blessed be God for't'. When work and resources were bestowed, wealth was not a reward, but rather an obligation. Parsons reflected that when entrusted with goods from God, 'we must soon give an account of our management'. ${ }^{28}$ As part of their religious and ethical conceptualizations of work, diarists used a group of terms including 'calling', 'vocation' and 'station' to discuss their labour. These words referred to work less as a task undertaken, and more as a form of obligation to be fulfilled. ${ }^{29}$ As Parsons wrote, 'Providence seems to increase my business and I must certainly pursue it - it is my duty'. ${ }^{30}$ Appropriately carrying out one's work as a 'duty' could bring material reward, while similarly, vice or failure to fulfil duty could result in wealth lost. As Harrold wrote, 'nothing more common than vice, yet nothing so much debases a mans courage, whereas virtue brings with it both pleasure and profit and easiness of mind and conscience'. ${ }^{31}$ Even the more secularlyminded John Cannon understood work and wealth within a code of Christian ethics. Reflecting on the working practices of a broker, who spent money as if it were his own, Cannon wrote that 'a secret curse goes with goods ill-gotten... But goods and wealth honestly gotten will endure to all posterity according to the words of Solomon'. ${ }^{32}$ 
While the diarists wrote of 'business' or 'duty' to refer to the broader management of labour, they had other vocabularies to describe more specific responsibilities. 'Work' was a word used broadly to describe the specific tasks performed either by the diarists themselves or by others, and which seemed to lack connotations of management. At times, it had undertones of manual labour. In Harrold's text, work was often associated with physical effort. He often wrote of 'working hard' or 'working close'. In 1712, he recounted 'I worked close at reversion wig' (a style of reverse-curled wig)', and later 'worked close till 8'. On other occasions, he described how he 'got up at six and worked hard' and 'sweat hard'. Here, work was used to describe tasks associated with some sort of material gain or remuneration. Parsons used another related word, 'living', to describe activity undertaken for material gain, probably a derivative of the common contemporary phrase 'living by one's labour'. Harrold prayed to God to 'get into a method of living well and comfortably', and thanked heaven for being out of debt. ${ }^{33}$

While the three diarists used a clutch of terms to refer to the business of making a living, including 'work', 'business', or 'living', and the obligations of duty or calling, they employed yet other vocabularies when writing about more social or intellectual forms of work, namely their participation in intellectual or scientific activity and the pursuit of knowledge. Like many men of their generation, Parsons, Harrold and Cannon participated in a public and increasingly available world of science and letters. Parsons was an avid reader and noted purchasing and reading a variety of Enlightenment texts, including Newton's Optics (1704) and Burnet's Theory of the Earth, two volumes on the origin of the cosmos, published in the $1680 \mathrm{~s}$. He also conducted amateur experiments. In one entry, Parsons noted having 'spent a good part of this day in filling thermometers to a proper height and sealing them.${ }^{34}$ Cannon and Harrold shared a similar interest in learning and books. To describe this intellectual or scientific labour, diarists used the word 'imploy' or 'employment'. John Cannon, who stole time away from his agricultural labour to read in the hedgerows, counted reading as one of his many 'employments'. ${ }^{35}$ Parsons described being 'imploy' $d$ as usual in drawing' and later being occupied by 'my own private imploy - reading (just now) Newton's Optics copying some of Worlidge's Etchings' ${ }^{36}$ 
It might be tempting to classify reading and amateur science as forms of leisure, distinctive from making a living. However, if the ability to make a living depended not only upon the act of production, but on the cultivation of an environment and a social status in which such production would be possible, then the definition of 'work' might be expanded further to include not only forms of labour that were not paid, but also forms of leisure that were not merely pleasure. For the three diarists, work was not only any activity which generated income, or provided an alternative to income, but was also understood to be a social practice that generated status. The different vocabularies and languages used by diarists to describe how they spent their days complicate historical definitions of 'work'. Rather than distinguishing between work and leisure, paid and unpaid work, or work that took place domestically or was external to the home, the diarists described their tasks in terms of a more diffuse understanding of reward that took issues of fulfilment and status into account alongside material gain.

From one perspective, books served important economic functions as material assets and forms of investment or savings. Collecting books might be conceptualized as a financial strategy. As repositories of value, books, like other material objects, could be exchanged and sold at crucial moments in the credit cycle. During moments of financial crisis, Cannon noting making arrangements to have books appraised and sold. ${ }^{37}$ Harrold borrowed, loaned, read and reflected upon his printed material, but he also conceptualized his book trading in terms of profits and losses. He used his diary as a space both to copy out passages from historical and religious texts and to carefully account for what he purchased and sold, noting profits and losses. In one entry, reflecting on a recent purchase and on the state of his library, Harrold wrote that he 'Bought 16 books for self and more. Bought 8 for others [including] Samuel Oakes and John Whitworth. Sold 2 for good profit again to WD and Laurence' ${ }^{38}$ From a different perspective, as important as their concrete value, books provided the diarists with a means of acquiring knowledge. By the late eighteenth century, as John Rule asserts, men saw skill as a possession. Earlier in the century, the three diarists seemed to commodify their knowledge in similar terms. The property of knowledge was essential to credit and could be commodified, sold, or marshalled into forms of work. As John Money has suggested, knowledge and the ability to talk, listen and remember 'amounted to an exchangeable fund which served as the specie of a commercial 
sociability... knowledge ceased to be simply a medium of exchange to be used for temporal advantage and became a very personal possession'. 39 John Cannon was introduced to knowledge as a saleable commodity early in life. While visiting an ale house, his friend Stephen Bush asked an excise officer, Mr Bosley, 'if he would sell his trade for he would buy it', to which Bosley replied that he would teach them' his trade

for forty shillings each. ${ }^{40}$ Cannon clearly saw the acquisition of knowledge as a form of investment that would help him on a path towards upward mobility. Later in life, knowledge became a primary source of credit and employment. He survived through what he called 'employment at intervals', which consisted of charging fees for 'forms of writing and accounting'. 41

\section{KNOWLEDGE, STATUS AND TITLE}

Thinking about reading and intellectual pursuits as a form of work disrupts the status load carried by occupational title. Even if we acknowledge occupational titles to be fictions in the world of work, we often regard them as indications of status and lineage. ${ }^{42}$ However, diaries suggest that in the eyes of middling people, a title was not necessarily the most elevated form of social standing that a man could claim from his labour. The three diarists derived status from work, separately from their occupational titles. For an upwardly-aspiring middling sort, a title could be seen as limiting and inflexible, while other forms of productive activity and the possession of knowledge as a form of property provided better opportunities for self-fashioning. Thomas Parsons had a particularly ambiguous relationship with his occupational title. As a guild-trained carver and the master of his workshop, occupation theoretically ought to have provided a positive source of local, civic status. However, Parsons wrote of his title as a burden and as a detriment to financial gain. In one entry, he even fantasized about casting his title off, reflecting ' $I$ find myself in a business that is not so well as to profit, as I think I cou'd get with the same attention by working as a journeyman'. ${ }^{43}$ In a later entry, he wrote of resenting the responsibility for management that came with being a master, implying that business prevented mobility by denying him time to acquire knowledge: 'I starve my mind in the attainment of 40 or 50 pounds a year! And spend my thoughts and time about this little Business as if it was ten times as much' ${ }^{44}$ Not only did Parsons gain more status from his intellectual endeavours, but in surmising that he 
might make more money as a journeyman, his comments suggest a feeling that in the rapidly changing building industry, his occupational title and status limited his ability to make a living.

Both Parsons and Cannon expressed their own worth and judged the worth of others according to the demonstration of knowledge and skill rather than the claim to a title or the possession of wealth. Parsons took great pride in possessing a mind 'superior to the crowd', and he assessed other artisans according to the degrees to which they possessed knowledge, at one point criticizing 'illiterate tradesmen'. His capacity for intellectual pursuits allowed him to distinguish himself from his workmen. Parsons wrote of one of his apprentices that he had 'the Mind of a country fellow who has never perhaps thought of reading etc but plods on in one contracted sphere, [and] will with great difficulty make any considerable attainment'. ${ }^{45}$ Cannon judged himself and others according to similar co-ordinates, noting especially the possession of knowledge and literacy. He wrote disparagingly of 'Mechanicks such as Black Smiths, Tanners, Taylors, Chandlers, Woolcombers etc. whose learning is so rife [indiscriminate] that they could as well distinguish the wrong end of a Warrant uppermost as the right way'. ${ }^{46}$

Participation in scientific enquiry was an important means of claiming status. As Henry French suggests, the qualities of science overlapped with the qualities of genteel status, reinforcing one another. Establishing reputations as thinkers allowed middling men to step out of local and competitive estimations between craftsmen, based upon financial ability, business volume or civic responsibility. ${ }^{47}$ For Parsons, Cannon, and Harrold, though, I would argue that learning did even more. A reputation for knowledge provided a stable sense of self and credit that transcended the precariousness of work, which included not only multiple employments, but financial insecurity and a changing occupational landscape. Cannon understood the condition of moving from job to job as being insecure. Later, reflecting on his career trajectory in 1734, he wrote that 'from a schoolboy I became a plowboy, from a plowboy an Exciseman from an Exciseman a Maltster from a Maltster to an almost nothing except a Schoolmaster' ${ }^{48}$ In this insecure world, reading provided a point of continuity. As he reflected, 'for all these my hard and laborious employments I never slighted or disregarded my books, the study of which augmented and much increased my understanding'. John Money suggests that reading 
and writing provided Cannon, as a self-described 'tennis-ball of fortune', with a way to convince himself that he was not an 'almost nothing'. ${ }^{49}$ Rather than looking upwards and aspiring towards gentility, the pursuit of knowledge was part of a descending gaze and an effort to avoid downward social mobility.

For Parsons, the pursuit of knowledge was a means of coping with a changing artisanal landscape. During his coming of age as a stonecutter, the professional status of artisans was put under threat by a newly professionalized artistic culture that depended on drawing status distinctions between the artist and the craftsman. British artists attempted to carve out a new identity for themselves, refuting the notion that they were little better than ordinary mechanics. ${ }^{50}$ Emergent British theories of painting defined painting as a liberal art and an intellectual activity, which sat in distinct contrast to the craftsman's manual labour. This idea was reflected in texts like Sir Joshua Reynolds's Discourses on Art, where he distinguished between the 'liberal professional' who 'works under the direction of principle', and the 'mechanical trade', which was carried out by men of 'narrow comprehension and mechanical performance' in obedience to 'vulgar and trite rules'. ${ }^{51}$ The capacity for judgment, or taste, set the artist and the craftsman apart. These theories both created professional distinctions and had social and civic consequences, denigrating the craftsman in particularly gendered ways. While the artist was cast as the enfranchized citizen or the independent man, the craftsmanmechanic was depicted as servile.

Parsons penned his diary in 1769 , the same year that the Royal Academy was founded: an institution that was central to the professionalization of the arts. ${ }^{52}$ Parsons's diary provided a space for him to engage with these discourses, and to position and account for his labour against the central features of artistry versus craft that formed the intellectual and cultural context for his work. He went to great lengths to claim an aptitude for judgment and taste. Self-instruction through reading and amateur experimentation took him beyond the 'narrow interests' of mechanics. He wrote of experimenting with materials, for example melting glass and bringing it into a paste. Gaining a deeper understanding of the scientific qualities of his materials differentiated his labour from that of the humble craftsman bellow him. This self-fashioning through intellectual pursuits went hand-in-hand with his attitudes towards manual labour. He wrote of disliking manual labour, and though his work was very often manual, he rarely 
emphasized his physical attributes, such as bodily strength, when discussing his work. Only when recounting an accident in which his hand was injured while moving a statue did Parsons acknowledge the importance of his material body to his working identity. Recounting the incident, he wrote of being 'very much vexed because I know 'twou'd hinder my working a long time'. ${ }^{53}$

Office-holding constituted another form of unpaid work that is crucial to account for when we consider male status and identity. As householders, Harrold, Cannon and Parsons were three of the some 400,000 individuals in eighteenth-century England who were expected to assume civic responsibilities, and who made up the pool from which parish officers were drawn. ${ }^{54}$ All three diarists were designated as 'inhabitants', a status signifying that an individual was a ratepayer, which carried connotations that he or she possessed a material stake in the parish community. ${ }^{55}$ Harrold was elected as a muzzler 'of mastiff dogs and bitches' in 1713. Cannon referred periodically to his duties as 'officer' and parish accountant. According to Henry French, assuming these civic roles at the parish level was one of the defining elements of middling social identity, which distinguished individuals as "chief inhabitants'. ${ }^{56}$ The experiences of undertaking civic responsibilities, as described by the three diarists, suggest that they could indeed be important sources of status. Harrold noted when others had been elected for Leet Court, as well as the occasions when he attended and who else was there. ${ }^{57}$ But just as occupational title had a limited bearing on status, so the impact of office holding was partial. The diaries suggest a slightly different urban middling relationship with the state than the rural world of the parish described by French. First, relying on parish office as the main indicator of status leaves out middling dissenters, who were increasingly numerous in the eighteenth century. Thomas Parsons, a Baptist dissenter, recounted undertaking civic responsibilities within the national dissenting community rather than the parish, including visiting, caring for the ill, money-lending and welcoming travelling ministers. ${ }^{58}$ Second, office-holding and the tasks associated with this role competed with other forms of work as indicators of status. Harrold's diary gives the distinct impression that civic tasks were something that he was co-opted into, and which called him away from more fulfilling or profitable work. As Craig Horner suggests, civic posts had different levels of status. While office-holding could indicate ratepaying status, a civic title could also reflect or imply low standing in town society. 
Civic duties sometimes came in the form of paid work, conferred on individuals as a form of quasi-charity. Thus, when elected 'dog musiller', Harrold missed the swearingin ceremony, for which he was fined. ${ }^{59}$

\section{MASCULINE INDEPENDENCE AND THE LIFE-CYCLE}

Work and working life had a crucial relationship to one of the central features of eighteenth-century masculine identity: independence. ${ }^{60}$ In turn, a man's capacity for independence depended upon his life-cycle position. While historians have long recognized the importance of marital status to women's employment opportunities, the importance of life-cycle to male labour is less well conceptualized. In its simplest form, work created the income that allowed men to claim a reputation for self-sufficiency, which was understood in terms of being able to maintain oneself without relying on others. By the eighteenth century, maintenance in terms of income came to constitute one of the primary means by which many people claimed their status. ${ }^{61}$ Income and self-sufficiency also supported male gender identities within the household, allowing men to claim the ideal of provisioning, and in turn, to benefit from the dividends of patriarchy. All three diarists earned a comfortable though modest subsistence for tradesmen of the time, earning between fifty and seventy pounds per year, which placed them squarely within the lower bounds of the 'middling' in terms of income.

If income provided the basis for independence, this independence was not secure. All three diarists fretted frequently about paying their debts, and feared potential failure. Harrold often had difficulty paying rent, noting in one entry that he was forced to sell his grey mare in order to satisfy his landlord. ${ }^{62}$ Parsons agonized about his financial obligations, noting in one entry 'am in debt and know not how to pay. This gives me great uneasiness - what a multiplicity of concerns have I to employ my thoughts!'. ${ }^{63}$ Just as divine providence could bestow wealth, so it could take riches away. Debt combined temporal and religious anxieties. As Harrold reflected, 'the world and the things of the world are mutable'. ${ }^{64}$ In October of 1713, he thanked God for 'tolerable business' and noted 'I live very comfortablay'. By the next month, he would write that he was 'ill set for money. Very dull business... A great rent and little trade, so that I'm in great straite what to do'. ${ }^{65}$ Given the fragility of financial self-sufficiency, work's contribution to an independent status was conceptualized less in terms of material gain, 
and more by the relationships that working life conferred. Work was a social practice, and the social relations structuring and structured by eighteenth-century working lives were as important to a reputation for independent status as the tasks that individuals undertook or the material benefits that they derived from productive activity. Working life placed lower-middling men into relationships with family, apprentices and other craftsmen that were based on dependence, status and hierarchy. Thinking about work in terms broader than monetized labour allows us to probe the limitations of the eighteenth century's independent economic man.

Just as life-cycle position had a bearing on women's work, the kinds of relationships that men established through work, and the degree to which these supported claims to independence, depended upon their place in the life-cycle. Thomas Parsons devoted many lines in his diary to hierarchical relationships of work with his father. Aged twenty-five at the time he wrote the diary, Parsons served nominally as the 'master' of his workshop, but found himself in a transitional life-cycle stage, in the process of taking over the business from his father. Parsons therefore occupied a liminal space between independence and dependence; between patriarchy and subordination. He recounted his father's criticisms over the management of his business and the ways that he spent his time. Fashioning a working self that was independent proved a constant source of anxiety for Parsons, who often wrote about his desire for a different means of making a living: 'I have often thought of, and wish'd for some other way of getting my bread, so as to be detach'd from my Father'. ${ }^{66}$ Similarly, Cannon complained of his parents' meddling in his employment opportunities. He believed that parents should allow their children to 'seek honourable employments and honest callings' suitable to their skills, and resolved in 1720 'to get in some employ that should separate me from them a good distance'. ${ }^{67}$ Parsons's and Cannon's experiences make clear that while the household family provided a source of security and the means to achieve a patriarchal status, the collusion of work and family also posed challenges for men in subordinate positions as they sought to establish independent working identities.

Diaries served young men as spaces in which to fashion an independent self by deploying a language of paternalist discourse. In describing his work, Parsons claimed independence by placing himself within a hierarchal working relationship above journeymen, apprentices and other dependents, which gave him a partial claim to 
patriarchal dividends. For example, as a nominal patriarch, he expected to 'gain credit' from his journeymen. As studies of credit and reputation have made clear, male reputation was derived from men's own actions as well as the positive and negative reputation of dependents and family. ${ }^{68}$ Upon hiring a journeyman, he reflected that this individual would 'prove a workman and a credit to his Master who intends also to be his instructor'. 69

As men transitioned from positions of dependence and youth to positions of potential patriarchal authority, the complex relationship between work, family and independence changed. Male working identities came to be constructed in relation to the work of their dependents. Though conduct literature placed a heavy emphasis on the ideals of patriarchal provision, we know that household economies did not in reality rely solely on the capacity of a patriarchal bread-winner. Furthermore, wives were not merely helpers, but in many cases held their own independent occupations. ${ }^{70}$ The extent, however, to which men recognized the contributions of their dependents and partners, and how they made sense of them in the formulation of their own occupational identities is more opaque. On the one hand, as Karen Harvey asserts, household management was a co-operative endeavour. On the other, the roles of women as central to household earnings would seem to betray the ideal of the independent, autonomous man. As Joanne Bailey suggests, 'co-dependency worked against male autonomy'. ${ }^{71}$ Tensions could arise between the idea that maintaining a livelihood was a co-operative undertaking, and the notion that work was essential to establishing individual identities.

Diaries suggest that in non-institutional contexts, men recognized and even expected women to provide household labour. The expectation that a wife's work would contribute to the financial well-being of the household started at courtship. For the young Thomas Parsons, anxieties about finding a suitable marriage partner were bound up with concerns over solvency and financial competency. He judged the women that he met according to their skill. Similarly, the widowed wigmaker Edmund Harrold wrote about his decision to remarry after his first wife's death as being bound up not only in loneliness, but in the need for a new wife to contribute to household provisioning. Fretting over the decision of whether to marry or not, he wrote 'I'm much concerned about my affairs'. In describing one potential courtship partner he used a language of management: 'she [is] a maneger, but is manag'd. She wants to be 
satisfied'. ${ }^{72}$ Harrold's comments suggest that to some extent, men subscribed to the notion identified by Ågren and her colleagues as the two-supporter model: husband and wife needed to work together to support their common livelihood. ${ }^{73}$

Within lower-middling households, business decision-making and oeconomic management were joint endeavours. Harrold's economic relationship with his wife might be described as co-operative. In his diary, he referred to Sarah as his 'assistant'. He read his business letters to her before sending them. Decisions related to renting lodgings in their household were made jointly or deferred to his wife. Sarah was intimately involved in debt collection and the decision to 'dun' those who were obligated to the Harrold household. She also had input into his exchange decisions. In 1712, Harrold 'swapt 1 wig with Rob Parley of Whitehaven for 1 wig and 2 boxes, long ones, of wood'. Apparently responding to her discontent with the bargain, he later noted having 'swapt and unswapt with Robert Parley to please wife' ${ }^{74}$

If men like Harrold shared household provisioning and decision-making with their wives, and though we might describe their relationships as co-operative, the task of managing and keeping track of household production seemed to be a more masculine endeavour. Accounting linked men's everyday practices to notions of masculine oeconomy. ${ }^{75}$ In the pages of his diary, Harrold accounted for his wife's labour alongside his own, keeping track of how 'busie' she was, and what kinds of work she completed during the day, even where this work was independent of his wigmaking business. On 25 July he noted his wife's progress in making bread: 'About 1/4 past my wife was kneading and she had teemed the barm' [meaning drained off the yeast]. He noted how productive she was, writing in one entry that 'My wife made all her mak' [meaning that she was arranging the house], and in another that she cleaned out stock while he worked. ${ }^{76}$ Male oeconomic management might seem contradictory to previous accounts showing that women were often responsible for household management. Marriage, by some accounts, gave women authority over the household and power to command the labour of others. ${ }^{77}$ However, control over economic resources and household authority were also clearly part of gender difference. If we were to observe the household diary of a woman, we would be unlikely to find her accounting for her husband's work.

Harrold benefited from the task of oeconomic management, which gave him power over the household. However, diaries suggest that household management roles 
did not come easily. Accounting was negotiated between husband and wife, and men were judged according to the skill and success with which accounting was performed. Wives expected their husbands to manage effectively and questioned their abilities to do so. Harrold wrote that Sarah 'asked questions about books'. ${ }^{78}$ In the Cannon household, management was not John's sole prerogative. He wrote that his wife 'consented' to his selling property in order to pay off their debts, and she criticized his ability to effectively manage their household resources. In 1728, when the family was in particularly bad straits, Susanna told him 'that she and the children must spin only to support such a lazy, indolent fellow as I was... who had for a great many times past had a very fair opportunity to have made a sufficient provision for himself and his family but took no further care than for the present time, and that I riotously wasted that which might have been treasured up for future support' ${ }^{79}$

Lower-middling households were clearly joint ventures. However, we must be careful not to over-emphasize the extent to which this sense of co-operation influenced male work identities. Men acknowledged the work of their wives in household accounting. However, when they reflected on how work gave them status and satisfaction, the work of the household as a whole was rarely in mind, only their own. This could be partly related to the individualistic nature of diary-writing. Diaries served as spaces for what Jason Scott-Warren calls 'makinge up', or what Matthew Kadane refers to as 'watchfulness', an examination of the self which was conceptualized both as a spiritual process meant to cultivate personal piety, and as a form of more secular constructions of industriousness. ${ }^{80}$ The diary as a form of record keeping encouraged an obsession with selfhood. As Edmund Harrold described, 'it is every mans duty to examin and communicate'. He went on to explain, 'from this way of living springs al[1] our comforts of long life riches and honours, a good name, and peace of conscience'. ${ }^{81}$

The diarists' appreciation of female and co-operative productivity was made most clear in cases of indisposition. In Cannon's case, his wife's contributions became apparent when he fell ill and was unable to provision the household. While he was in 'a low condition', his family depended upon the labour of his wife, who 'took up the trade of selling bread for the bakers and butter for the dairy folks, in which she continued about two years'. ${ }^{82}$ Although Harrold accounted for his wife's activities frequently in his diary, the real extent of her financial contributions was only acknowledged after her 
death, when he was forced to assume tasks that she once carried out, or to hire help to perform them. He wrote of being 'busie in the house', and later of having 'both shops to tend now, all by plunges' [in a hurry or with difficulty]. ${ }^{83}$ Five days after her burial, Harrold hired a housekeeper. He was forced to take on new by-employments, lodged strangers, and began selling off household goods. He enlisted his sister in law, Martha, to help to manage his daughter Anna's education and bringing up. As time progressed, Harrold fought to single-handedly maintain his household and support his young children. He spiralled into debt. Without Sarah, he found himself 'in great straite what to do'. 84

Over the course of the life-cycle, working identity continued to change. Just as working identity shifted in the transition from youth to middle age, and as men assumed positions as heads of household, so their identities shifted again in old age as their ability to work declined. Because work was so important to male selfhood, this transition into old age poses conceptual problems for the historian. When men stopped working, how did their occupational identities change? Some men maintained their occupational identities after retirement. Keith Thomas suggests that unlike today, retirement in the early modern period did not require a complete disengagement from occupational life. ${ }^{85}$ However, by the eighteenth century, it came to be expected that older men would withdraw from their professions, or at least hire additional help. ${ }^{86}$ Susannah Ottaway has argued that in eighteenth-century England, self-sufficiency and autonomy were the central ideals of old age, shaping attitudes about whether or not the aged should labour. The view that individuals should continue working until they reached decrepitude was matched by a developing attitude that it was acceptable, or even desirable, for those of middling status who had achieved independence to retire from work. ${ }^{87}$

Occupational plurality facilitated the transition into different occupations later in life. Men might take up work that relied less on physical strength and agility. Thus, Thomas Parsons's ageing father Robert, once the master of the stone-cutting workshop, followed spiritual aspirations and began lecturing as a Baptist minister. Diaries suggest that for middle-rank men who possessed independent businesses, old age seemed to involve less a complete stepping away from work, and more a long period of semiindependence as they handed over some tasks and responsibilities to younger family 
members. Parsons's diary recounts father and son working together. In January, he described being 'employed myself with my Father in getting the pieces of timber from the top of the orchard to the pit'. Later that month, he showed his father a copy of a popular print, a gesture that led to an argument about taste. Thomas Parsons's father continued to maintain oversight of the stone-cutting workshop, which prevented his son from claiming full independence. They constantly disputed tasks and working methods, as Thomas attempted to assert his independence. In one typical entry, he noted that 'Father seem'd chagrin'd at refusing to comply with his proposal - telling me that was but one among many instances in which his mentioning a thing was a sufficient reason for my objecting to it ${ }^{98}$ Other diaries suggest similar practices of partial retirement. When the grocer William Stout of Lancaster handed over his shop to his apprentice, John Troughton, he maintained oversight of the business from a distance and returned to manage affairs when Troughton fell into bankruptcy. Older men like Stout felt that maintaining partial control was a responsibility towards the interpersonal obligations that he built over his career. As Stout reflected, as former owner of the business and the person who secured Troughton's credit, 'I thought my selfe obliged to use my endevors to make the most for the crediters' ${ }^{89}$

\section{CONCLUSION}

Work was, for lower middling men, a central feature of identity and of status. However, this status was dependent neither solely or even principally upon occupational title, nor upon the income derived from productive activities. In order to truly understand what work meant to the people who performed it, we have to start somewhere else than with occupational titles or incomes. ${ }^{90}$ Working identities were derived from a more complex accounting for the different activities that men undertook during their working lives. In order to understand the functions that work played in constructions of masculine selfhood, we require a broader definition of what constituted 'work'. This definition must take into account activities that did not generate income and which might not even be considered straightforwardly 'productive', but which provided men with a means of developing and asserting skill and status. In a credit economy, cultivating a reputation for skill and status was inseparable from 'making a living'. Early modern working lives, then, challenge economic definitions of value. The 'value' of a job was not only 
conceptualized in financial terms. It was also social, reputational, and fulfilling. Men understood their work as an undertaking that established skill, status, independence and self-worth, in addition to being a productive activity to provide maintenance or to generate income.

'Work' could include activities that were not paid, but also leisure that was not just pleasure. Men like Parsons, Harrold and Cannon clearly understood their work as encompassing a broad range of activities, and they employed complex vocabularies, using the words 'work', 'business' and 'employment' to describe the different but interrelated benefits conferred by their different forms of work. The benefits of work, forged in a precarious environment, could be financial, but they could also be social, related to public reputation and to relationships of power forged especially within the household. In contributing to a man's broader sense of worth, different forms of work could have inverse or contradictory relationships. Thomas Parsons made most of his money from his stone-cutting business rather than his intellectual pursuits, but it was from his participation in an intellectual world of scientific experimentation that he derived the most status. Furthermore, work did not only confer 'benefits'. Given the precariousness of working lives, including financial instability, changing occupational landscapes, and potential crises of various kinds, work was not necessarily a positive source of identity for lower-middling men. For upwardly-aspirational men in different places in the life-cycle, occupational title and position could be limiting. While work could contribute to independence, it could equally challenge or undermine male autonomy. Work was a social practice performed in co-operation with or in relation to other people. Relational meanings of work changed over the source of the life-cycle. For younger or subordinate men, working practices confirmed dependent status. As men transitioned into positions of patriarchy, managing other people's work within the household became an important feature of independence. Finally, in old age, men negotiated their status as working life slowed or stopped.

A better understanding of male work and its values can be achieved by applying the insights derived from studies of female labour to male experiences of labour. We must also consider men's work in relation to the productive activities undertaken by their wives and by other members of the household. For most married men, work was performed in relation to and in co-operation with their wives, which might challenge the 
ideal of masculine independence and provision. In this sense, the relationship between male and female labour, and the ways in which working identities contributed to gender difference, emerge as both historical and historiographical problems. Economic identities are central to gender difference. Work, access to resources, and control over wealth have been central to defining what it meant to be a man and what it meant to be a woman. But we have perhaps been too ready to heed the fictions of the archive that link masculinities with single occupations, and that make male work seem so very different from female work. While acknowledging that men and women worked in different sectors and undertook different tasks, and that female work was often remunerated at lower rates, a broader understanding of male work tempers the influence that labour had upon gender difference in early modern Britain.

In an effort to decouple work from occupational title, previous studies have drawn a distinction between what people did and who they were. ${ }^{91}$ I would argue that these two concepts should remain intimately bound. What men did was crucial to the sense of self, in other words, to who they were. However, if we broaden the definition of work, the importance of occupational title fades, and it emerges as one of many relational categories. Multiple employments were central to middling male identities.

Tawny Paul is Senior Lecturer in History at the University of Exeter. She holds a $\mathrm{PhD}$ in Economic and Social History from the University of Edinburgh. She is interested broadly in gender and economic culture in early modern Britain, and is the author of a forthcoming monograph on debtors' prisons and downward mobility in the eighteenth century. While focusing on the early modern period, she believes that historical perspectives help us to understand and challenge financial and gender inequalities in the present. Her recent work has been supported by the Huntington Library, the National Endowment for the Humanities, and the Economic History Society.

\section{NOTES AND REFERENCES}

The author wishes to thank Mark Hailwood and the anonymous readers at History Workshop Journal for their helpful comments on previous drafts of this article. Aspects of the paper were presented at the Pacific Coast Conference for British Studies at the Huntington Library, April 2016, and to the 'Society, Culture \& Belief, 1500-1800' 
seminar at the Institute for Historical Research in London, Nov. 2016. Many thanks to the participants for both lively discussion and insightful questions.

NOTES AND REFERENCES

1 The Diary of Edmund Harrold, Wigmaker of Manchester, 1712-15, ed. Craig Horner, Aldershot, 2008 (henceforth Harrold Diary): date? 1, 3, 21, 25September 1713; 3 Oct. 1712; 11 Sept. 1712; 27 April 1713; 5 May 1713; 23, 24 Nov. 1714; 20-3 Oct. 1713.

2 Keith Thomas, The Ends of Life, Oxford and New York, 2009, p. 106; Mark Overton, Production and Consumption in English Households, 1600-1750, London, 2004, pp. 74, 76; Alexandra Shepard, Accounting for Oneself, Oxford, 2015, pp. 14990. For an argument against the prevalence of by-employments, see Sebastian A. J. Keibek and Leigh Shaw-Taylor, 'Early Modern Rural By-employments', Agricultural History Review 61, December 2013, pp. 244-81.

3 Harrold Diary, 15 Oct. 1713.

4 Keibek and Shaw-Taylor, 'Early Modern Rural By-employments'.

5 Jonas Lindström, Rosemarie Fiebranz, and Göran Rydén, 'The Diversity of Work', in Making a Living, Making a Difference: Gender and Work in Early Modern European Society, ed. Maria Ågren, Oxford, 2016, p. 6.

6 Thomas, The Ends of Life, pp. 100-1; Mark Hailwood, “"The Honest Tradesman's Honour": Occupational and Social Identity in Seventeenth-Century England', Transactions of the Royal Historical Society (Sixth Series) 24, 2014, pp. 79103.

7 Guy Standing, The Precariat: the New Dangerous Class, London, 2011, p. 32; Deborah Fahy Bryceson, How Africa Works: Occupational Change, Identity and Morality, Rugby, 2010.

8 Harrold Diary, 21 Oct. 1712.

9 Malcolm Chase, Early Trade Unionism, Aldershot, 2000; Shepard, Accounting for Oneself, p. 268; Thomas, The Ends of Life, pp. 106-7; Brodie Waddell, God, Duty and Community in English Economic Life, 1660-1720, Woodbridge, 2012, p. 205.

10 Mary Prior, 'Women and the Urban Economy: Oxford 1500-1800', in Women in English Society 1500-1800, ed. Mary Prior, London, 1985, p. 95. 
11 Making a Living, Making a Difference, ed. Ågren, p. 4. The verb-oriented approach used in the 'Gender and Work' project.identified active words in the historical record to collect people's productive activities. This methodology has the advantage of emphasizing what people did rather than what they were called.

12 Keibek and Shaw-Taylor, 'Early Modern Rural By-employments', p. 250.

13 Shepard, Accounting for Oneself, p. 232; John Rule, 'The Property of Skill in the Period of Manufacture', in The Historical Meanings of Work, ed. Patrick Joyce, Cambridge, 1989, pp. 99-118.

14 Thomas Parsons, 'Diary, 1769', Huntington Library, San Marino, CA, mssHM 62593, (henceforth 'Parsons Diary'), Location (Huntington?)

15 Leonore Davidoff and Catherine Hall, Family Fortunes: Men and Women of the English Middle Class 1780-1850, London, 1987.

16 For diaries as spaces for self-fashioning, see Felicity Nussbaum, The Autobiographical Subject, Baltimore, 1989; Patricia Meyer Spacks, Imagining a Self, Cambridge MA, 1976; Hannah Barker, 'Soul, Purse and Family', Social History 33, February 2008, pp. 12-35; Elaine Mckay, 'English Diarists', History 90, April 2005, pp. 191-212.

17 Jason Scott-Warren, 'Books in the Bedchamber', in Tudor Books and Readers: Materiality and the Construction of Meaning, ed. John N. King, Cambridge, 2010, pp. 247-9; Matthew Kadane, 'Self-discipline', in In Praise of Ordinary People: Early Modern Britain and the Dutch Republic, ed. Margaret C. Jacob and Catherine Secretan, Basingstoke, 2013, pp. 267-9.

18 Scott-Warren, 'Books in the Bedchamber', pp. 247-9; Craig Muldrew, 'Class and Credit', in Identity and Agency in England, 1500-1800, ed. Henry French and Jonathan Barry, Basingstoke, 2004, p. 172; Kadane, 'Self-discipline’, pp. 267-9.

19 Rosemarie Fiebranz, Erik Lindberg, Jonas Lindström, and Maria Ågren, 'Making Verbs Count', Scandinavian Economic History Review 59, November 2011, pp. 273-93; Sheilagh C. Ogilvie, A Bitter Living, Oxford, 2003.

20 Margaret G. Reid, Economics of Household Production, New York, 1934. For the application of this definition, see 'Adopting a New Methodological Approach to Early Modern Women's Work', University of Exeter, https://earlymodernwomenswork.wordpress.com/the-project/ 
21 Pierre Bourdieu, 'Forms of Capital', in Handbook of Theory and Research for the Sociology of Education, ed. John G. Richardson, New York, 1986, pp. 46-58. For a discussion of the different forms of capital in an early modern British context, see Keith Wrightson, Earthly Necessities, New Haven, 2000, pp. 290-6.

22 'Parsons Diary', 27 Jan. 1769.

23 Harrold Diary, 13 March 1713.

24 Karen Harvey, The Little Republic, Oxford, 2012, pp. 33-43, 64-6.

25 Harrold Diary, 30 Nov., 1713.

26 'Parsons Diary', 18 July, 1769.

27 Margaret R. Hunt, The Middling Sort, Berkeley, 1996, pp. 34-40.

28 'Parsons Diary', 15 Jan., 1769.

29 Waddell, God, Duty and Community, p. 98.

30 'Parsons Diary', 16 Jan. 1769; 13 Feb. 1769.

31 Harrold Diary, 31 Aug. 1712.

32 Chronicles of John Cannon, ed. Money, p. 8.

33 Harrold Diary, 26 June 1712; 5 Aug. 1712; 20 Aug. 1712; 12 Sept. 1712; 14 May 1713; 27 Dec. 1712.

34 'Parsons Diary', 30 Jan. 1769.

35 Chronicles of John Cannon, ed. Money, p. 36.

36 'Parsons Diary', 30 Jan. 1769; 27 Jan. 1769.

37 Chronicles of John Cannon, ed. Money, pp. 500-1.

38 Harrold Diary, 31 Dec. 1713.

39 Rule, 'The Property of Skill'; John Money, 'Teaching in the Marketplace', in Consumption and the World of Goods, ed. John Brewer and Roy Porter, London and New York, 1993, p. 353.

40 Chronicles of John Cannon, ed. Money, pp. 57-8.

41 Chronicles of John Cannon, ed. Money, p. 180.

42 Shepard, Accounting for Oneself, p. 232.

43 'Parsons Diary', 13 April 1769.

44 'Parsons Diary', 13 March 1769.

45 'Parsons Diary', 26 Jan. 1769.

46 John Cannon, quoted in Muldrew, 'Class and Credit', pp. 166-7. 
47 Henry R. French, “"Ingenious \& Learned Gentlemen”: Social Perception s and Self-Fashioning among Parish Elites in Essex, 1680-1740', Social History 25, 2000, p. 60.

48 Chronicles of John Cannon, ed. Money, p. 174.

49 Chronicles of John Cannon, ed. Money, p. cxxviii.

50 John Barrell, The Political Theory of Painting, New Haven, 1986, pp. 16-17.

51 Joshua Reynolds, Discourses on Art, ed. Robert R. Wark, New Haven (Paul Mellon Centre for Studies in British Art), 1975, pp. 93, 97, 117. Quoted in Barrell, The Political Theory of Painting, p. 15.

52 Holger Hoock, The King's Artists, Oxford, 2003. See especially chaps 1-3.

53 'Parsons Diary', 21 Feb. 1769.

54 David Eastwood, Government and Community in the English Provinces, 17001870, Basingstoke, 1997, p. 48.

55 Henry French, The Middle Sort of People in Provincial England 1600-1750, Oxford, 2007, p. 27. Edmund Harrold's father Thomas was a tobacconist and served on the Manchester Court Leet. Edmund seems to have achieved less civic status than his father. Parish entries list him as a 'barber' and a ratepayer: Harrold Diary, pp. xi-xii.

56 French, The Middle Sort of People, pp. 94-120.

57 Harrold Diary, 24 Oct. 1712, 6 Oct. 1712.

58 ‘Parsons Diary’, 5 Jan. 1769, 23 May 1769, 8 June 1769.

59 Harrold Diary, pp. xxvi, 20-23 Oct. 1714.

60 Matthew McCormack, The Independent Man, Manchester, 2005.

61 Shepard, Accounting for Oneself, pp. 191, 274.

62 Harrold Diary, 30 Aug. 1714.

63 'Parsons Diary', 27 Jan. 1769.

64 Harrold Diary, 30 Aug. 1712.

65 Harrold Diary, 15 Oct. 1713, 9 Oct. 1713; 28 Nov. 1713, 27-30 Dec. 1713.

66 'Parsons Diary', 13 April 1769.

67 Chronicles of John Cannon, ed. Money, p. 57; Muldrew, 'Class and Credit', p. 163.

68 K. Tawny Paul, 'Credit, Reputation, and Masculinity in British Urban Commerce', Economic History Review 66, February 2013, p. 240. 
69 'Parsons Diary’, 14 Feb. 1769.

70 Amy Erickson, 'Married Women's Occupations in Eighteenth-century London', Continuity and Change 23: 2, 2008, pp. 267-307.

71 Joanne Bailey, Unquiet Lives: Marriage and Marriage Breakdown in England, 1660-1800, Cambridge, 2003, p. 199.

72 Harrold Diary, 25 May 1713, 5 March 1713.

73 Sofia Ling, Karin Hassan Jansson, Marie Lennersand, Christopher Pihl and Maria Ågren, 'Marriage and Work: Intertwined Sources of Agency and Authority', in Making a Living, ed. Maria Ågren, p. 81.

74 Harrold Diary, 17 Dec. 1712, 29 June 1712, 16 June 1712.

75 Harvey, Little Republic, pp. 65-98.

76 Harrold Diary, 25 July 1712, 22 Nov. 1712, 23 Feb. 1714.

77 Ling and others, 'Marriage and Work', p. 95.

78 Harrold Diary, 27 Sept. 1712.

79 Chronicles of John Cannon, ed. Money, pp. 172-3, 189.

80 Jason Scott-Warren, 'Books in the Bedchamber', pp. 247-9; Kadane, 'Selfdiscipline', pp. 267-9.

81 Harrold Diary, 5 Oct. 1713.

82 Chronicles of John Cannon, ed. Money, p. 189.

83 Harrold Diary, 19 Sept 1712.

84 Harrold Diary, 25 Nov. 1712, 29 Nov. 1712, 22 Dec. 1712, 30 Dec. 1712, 14 Jan. 1713, 31 Dec. 1712, 6 Jan. 1713.

85 Keith Thomas, 'Age and Authority in Early Modern England', Proceedings of the British Academy 62, 1978, pp. 236-7.

86 Susannah R. Ottaway, The Decline of Life, Cambridge, 2007, p. 68.

87 Ottaway, Decline of Life, pp. 66-8.

88 'Parsons Diary', 23 Jan. 1769, 30 Jan. 1769, 15 Jan. 1769.

89 William Stout, The Autobiography of William Stout of Lancaster, 1665-1752

(ed. Harland, 1851), ed. John D. Marshall, Manchester (Chetham Society), 1967, pp. $148-9$.

90 Lindström, Fiebranz, and Rydén, 'Diversity of Work', p. 26.

91 Making a Living, Making a Difference, ed. Ågren. 


\begin{abstract}
This article addresses the social, cultural and gendered meanings of men's work in early modern Britain. As has long been accepted for women, men's work should be seen as multiple rather than single-occupational focused. Drawing on the diaries of three middle-rank tradesmen from the eighteenth century, the article considers the different forms that work took, and how words denoting labour such as 'employment', 'work' and 'business' were actually understood. Men had a broad definition of work that challenges distinctions between labour and leisure. These various forms of work had diverse benefits, challenging narrower economic understandings of 'value'. Work was about more than making a living: it was a source of fulfilment, status and social identity. Work's value and contribution to identity and status changed over the course of the lifecycle. It was carried out and understood in relation to others, especially men's wives, rather than merely supporting notions of power and independence. By applying the insights drawn from studies of female work to men's productive activities, the article reformulates historians' understandings of the place of work in early modern men's lives.
\end{abstract}

